\title{
Perovskite-polymer hybrid solar cells with near-infrared external quantum efficiency over $40 \%$
}

\author{
Long Ye, Benhu Fan, Shaoqing Zhang, Sunsun Li, Bei Yang, Yunpeng Qin, Hao Zhang and \\ Jianhui Hou*
}

\begin{abstract}
In the past several years, conjugated polymers and organometal halide perovskites have become regarded as promising light-absorbing materials for next-generation photovoltaic devices and have attracted a great deal of interest. As the main part of this contribution, we describe the enhancement of near-infrared (NIR) photoresponse of well-known $\mathrm{CH}_{3} \mathrm{NH}_{3} \mathrm{PbI}_{3-x} \mathrm{Cl}_{x}$-based solar cells by the integration of bulk heterojunction $(\mathrm{BHJ})$ small band gap polymer:fullerene absorbers. Particularly, the integration of a commercially available polymer PDPP3T and PCBM-based BHJ boosts the peak external quantum efficiency (EQE) by up to $46 \%$ in the NIR region $(800-1000 \mathrm{~nm})$, which is outside of the photoresponsive region $(300-800 \mathrm{~nm})$ of conventional perovskite solar cells. This substantial improvement in the EQE over the NIR region offers an additional current density of $\sim 5 \mathrm{~mA} \mathrm{~cm}^{-2}$ for the control perovskite solar cell, and a high power conversion efficiency (PCE) of over $12 \%$ was obtained in the perovskite/BHJ-based solar cells. In addition, the insertion of the $\mathrm{BHJ}$ absorber consisting of a small band gap polymer PDTP-DFBT and PCBM also results in nearly $40 \%$ EQE for the perovskite/BHJ solar cell. The results also reveal that controlling over the polymer/PCBM weight ratio for a $\mathrm{BHJ}$ absorber is the key to achieving the optimal efficiency for this type of perovskite-polymer hybrid solar cell.
\end{abstract}

\section{INTRODUCTION}

The urgent need for high-performance, large-scale, and low-cost thin film photovoltaics is driving extensive research on new light absorber materials [1]. Owing to the outstanding properties of high absorption coefficients, bipolar charge transport characteristics, low exciton binding energy, and long exciton diffusion lengths, organolead trihalide perovskites are attractive light absorbers for realizing high performance thin-film solar cells [2-5]. Rapid advances in perovskite/fullerene planar heterojunction solar cells have been achieved over the past three years. In particular, the power conversion efficiency (PCE) has experienced a dramatic increase in excess of $10 \%$ by utilizing an inverted structure (Fig. 1a) of indium tin oxide (ITO)/ poly(3,4-ethylenedioxythiophene) PEDOT: poly(styrenesulfonate) (PSS)/peroskite/ [6,6]-phenyl-C61-butyric acid methyl ester (PCBM)/Al(or Ag) [6-19]. For this type of peroskite/PCBM solar cell, generally only photons in the ultraviolet-visible range $(300-800 \mathrm{~nm})$ are harvested in the devices due to the medium optical band gap $(\sim 1.55 \mathrm{eV})$ of $\mathrm{CH}_{3} \mathrm{NH}_{3} \mathrm{PbI}_{3-x} \mathrm{Cl}_{x}$ or $\mathrm{CH}_{3} \mathrm{NH}_{3} \mathrm{PbI}_{3}$. Solution-processed polymer solar cells utilizing conjugated polymer and PCBM bulk-heterojunction (BHJ) blend as a light absorber are also a promising photovoltaic technology due to tunable absorption features and energy levels, as well as excellent solution processibility of the diverse polymers [20-29]. Therefore, integrating the advantages of both photovoltaic technologies into a simple photovoltaic device will be of great importance to achieve cost-effective and low temperature processed photovoltaic technologies.

It is well-established that nanoscale bicontinuous interpenetrating networks in polymer:PCBM BHJ solar cells are beneficial for realizing efficient exciton dissociation and charge transport [30,31]. Very recently, researchers from polymer solar cell community have introduced feasible strategies to push forward planar junction perovskite/ fullerene solar cells [32-36]. For insance, Liu et al. [33] integrated polymer:PCBM $\mathrm{BHJ}$ into a conventional device containing $\mathrm{ITO} / \mathrm{TiO}_{2} / \mathrm{CH}_{3} \mathrm{NH}_{3} \mathrm{PbI}_{3-x} \mathrm{Cl}_{x} / \mathrm{MoO}_{3} / \mathrm{Ag}$ and found that the perovskite/BHJ solar cell yielded an improved photocurrent and PCE. Nevertheless, the utilization of $\mathrm{TiO}_{2}$ may not meet the requirements for low temperature processing. Alternatively, Gong's group [34,35] introduced perovskite:fullerene $\mathrm{BHJ}$ and found that solar cells based on perovskite:PCBM BHJ function better than conventional perovskite/PCBM planar junction solar cells, and large fill factors (FF) of up to $\sim 80 \%$ can be achieved in this type of photovoltaic device. Zuo and Ding [36] also

State Key Laboratory of Polymer Physics and Chemistry, Beijing National Laboratory for Molecular Sciences, Institute of Chemistry, Chinese Academy of Sciences (ICCAS), Beijing 100190, China

*Corresponding author (email: hjhzlz@iccas.ac.cn) 
a

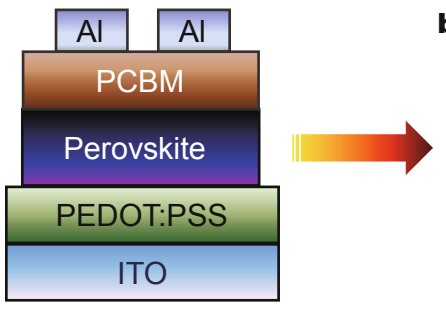

Perovskite solar cell b

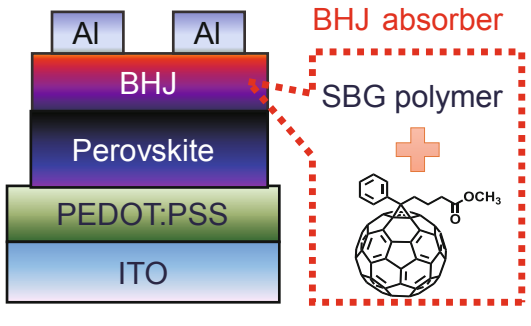

Perovskite-polymer solar cell (PPSC)
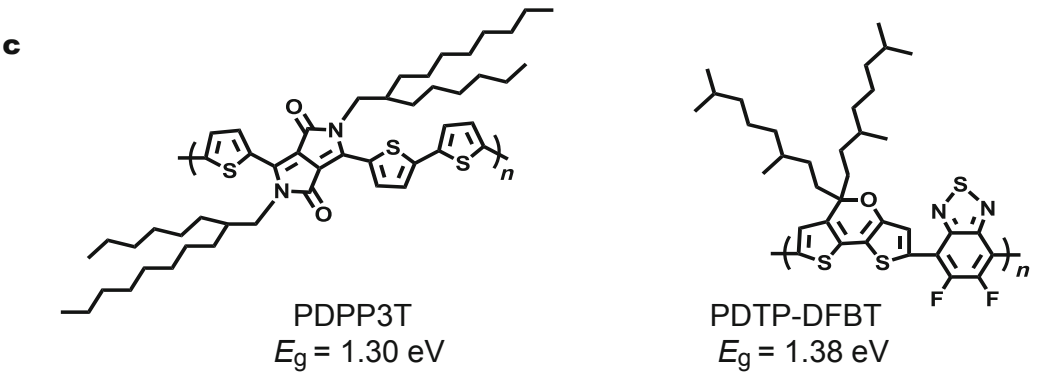

Figure 1 (a) Schematic illustration of the perovskite/PCBM solar cells, (b) schematic illustration of the perovskite/BHJ solar cells (PPSCs) and (c) chemical structures of the involved SBG polymers: PDPP3T and PDTP-DFBT.

integrated PDPP3T:PCBM BHJ into inverted $\mathrm{CH}_{3} \mathrm{NH}_{3} \mathrm{PbI}_{3}$ based perovskite solar cells and found that the near-infrared (NIR) photoresponse can be enhanced; however, the efficiency did not improve. Until now, the spectral responses in the NIR region of these integrated perovskite solar cells have limited the external quantum efficiency (EQE) to below 25\%. Boosting the NIR photoresponse without sacrificing the excellent efficiency of perovskite solar cells is still a great challenge in the field of hybrid solar cells. Accordingly, if the drawbacks associated with ineffective photon harvesting in the long wavelength region and improvements in the NIR EQE of the BHJ absorber can be overcome without sacrificing the primary $\mathrm{EQE}$ of $\mathrm{CH}_{3}$ $\mathrm{NH}_{3} \mathrm{PbI}_{3-x} \mathrm{Cl}_{x}$ absorber, we expect that the photovoltaic properties of these types of perovskite-polymer hybrid solar cells will be improved.

In this study, we successfully presented high-efficiency and broad photoresponse perovskite-polymer hybrid solar cells (PPSCs) by simply incorporating the small band gap (SBG) polymer:fullerene BHJ as an absorber (Fig. 1b). Compared with the control $\mathrm{CH}_{3} \mathrm{NH}_{3} \mathrm{PbI}_{3-x} \mathrm{Cl}_{x} / \mathrm{PCBM}$ solar cells, the novel perovskite/BHJ solar cells exhibited a $\sim 20 \%$ enhancement to short-circuit current density $\left(J_{\text {sc }}\right)$ and PCE. When the SBG polymer poly(diketopyrrolopyrrole-terthiophene) (PDPP3T) and PCBM blend was selected as the $\mathrm{BHJ}$ light absorber, a high photoresponse with an EQE of up to $\sim 46 \%$ over the NIR region $(800-1000 \mathrm{~nm})$ was observed. This resulted in a $20 \%$ enhancement to the $J_{\text {sc }}$ and PCE for perovskite/BHJ solar cells. Moreover, the
$\mathrm{BHJ}$ absorber based on the SBG polymer is also applicable to this novel perovskite/BHJ device configuration. Our study identifies a new direction in which to integrate polymer-based and perovskite-based solar cells is more effectively.

\section{RESULTS AND DISCUSSION}

Herein, the commercially accessible SBG polymer PDPP3T (Fig. 1c) is selected due to its low band gap $\left(E_{\mathrm{g}}\right)$ of $1.30 \mathrm{eV}$, high carrier mobility of $10^{-2} \mathrm{~cm}^{2} \mathrm{~V}^{-1} \mathrm{~s}^{-1}$ ) and broad absorption spectra that extends into the NIR region [37]. In previous reports [38-43], PDPP3T:PCBM BHJ yielded an approximately $50 \%$ external quantum efficiency (EQE) over the NIR region (800-1000 nm). Additionally, a desirable efficiency of $6 \%$ for polymer:PCBM BHJ solar cells has been reported in previous studies. The main absorption peak of the PDPP3T film is $850 \mathrm{~nm}$, which is located outside the spectral coverage of the perovskite absorber. Accordingly, the above-mentioned properties make PDPP3T particularly intriguing for detailed investigation as an NIR absorber in high-efficiency and low-cost hybrid solar cells. Fig. 2 shows the absorption spectra of the pure polymer $\mathrm{CH}_{3} \mathrm{NH}_{3} \mathrm{PbI}_{3-x} \mathrm{Cl}_{x}$ and the stacked perovskite/ $\mathrm{BHJ}$ in cast films. Compared with the perovskite film, the stacked $\mathrm{CH}_{3} \mathrm{NH}_{3} \mathrm{PbI}_{3-x} \mathrm{Cl}_{x} / \mathrm{PDPP} 3 \mathrm{~T}$ :PCBM film exhibited a red shift and complementary absorption. Besides, the absorption onset of the stacked film shifted to $\sim 950 \mathrm{~nm}$. As a result, a high $J_{\text {sc }}$ can be highly anticipated if the photons in the whole wavelength region are well utilized. 


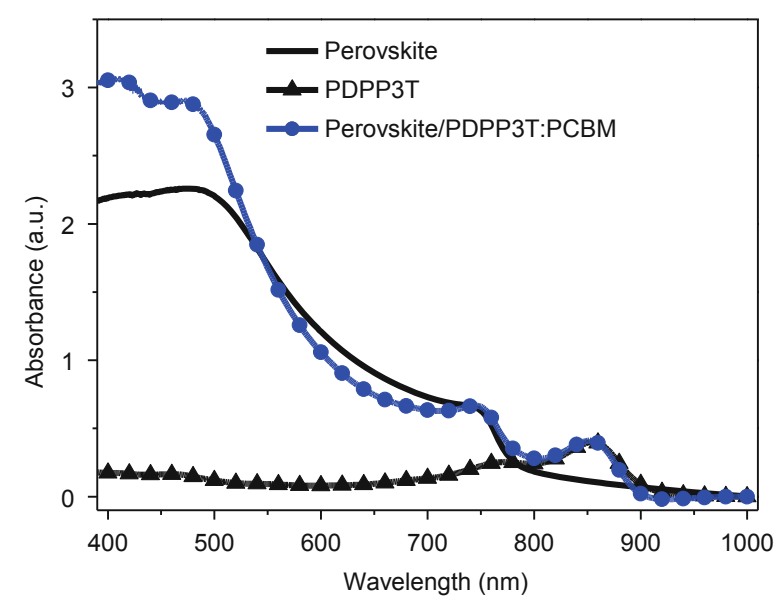

Figure 2 The absorption spectra of $\mathrm{CH}_{3} \mathrm{NH}_{3} \mathrm{PbI}_{3-x} \mathrm{Cl}_{x}$, PDPP3T and $\mathrm{CH}_{3} \mathrm{NH}_{3} \mathrm{PbI}_{3-x} \mathrm{Cl}_{x} / \mathrm{BHJ}$ films.

In a recent study, Zuo and Ding [36] observed a reduction in the PCE for $\mathrm{CH}_{3} \mathrm{NH}_{3} \mathrm{PbI}_{3}$-based solar cells after inserting a PDPP3T:PCBM BHJ layer. It has been reported that the surface roughness at the organic/perovskite interface is directly linked to the charge extraction and recombination $[4,5]$. We further examined using a BHJ layer with the same weight ratio may be a main reason for the efficiency decrease. Then, we proposed that the $\mathrm{BHJ}$ layer in polymer solar cells could not be applied directly to the PPSCs for the same weight composition, meaning that the polymer:PCBM weight ratio may need to be fine-tuned.

To verify this presumption, we further investigated the effect of weight ratios on the performance of PPSCs. Fig. S1 shows the current density $v s$. voltage $(J-V)$ characteristic curves with PPSCs employing different weight ratios (1:2, $1: 4,1: 6)$ for the PPSC BHJ layers. We conclude that a $1: 4$ weight ratio yields the best performance in PPSC devices (Table S1). The device parameters for the control perovskite:PCBM solar cells are also provided in Table 1 and Fig. 3a. Typical device performance (Fig. 3a) measured under $100 \mathrm{~mW} \mathrm{~cm}^{-2}$ illumination (Class AAA solar simulator and KG3 filtered reference cell) revealed an outsanding $J_{\text {sc }}$ of $22.9 \mathrm{~mA} \mathrm{~cm}^{-2}$, an open-circuit voltage $\left(V_{\text {oc }}\right)$ of $0.93 \mathrm{~V}$, a FF of $57.1 \%$, and a desirable PCE of $12.2 \%$ for the PPSC device. The corresponding values for the control device were $18.2 \mathrm{~mA} \mathrm{~cm}^{-2}, 0.89 \mathrm{~V}, 63.6 \%$ and $10.3 \%$, respectively. The novel PPSC device also outperformed the polymer-based PDPP3T:PCBM BHJ solar cell device (see Table 1 and Fig. S2), which exhibited a relatively low efficiency of $6.2 \%$.

Table 1 Typical photovoltaic properties for various types of solar cell devices under AM $1.5 \mathrm{G}$ and $100 \mathrm{~mA} \mathrm{~cm}$

\begin{tabular}{|c|c|c|c|c|c|}
\hline Perovskite layer & BHJ layer & $V_{\mathrm{oc}}(\mathrm{V})$ & $J_{\mathrm{sc}}\left(\mathrm{mA} \mathrm{cm}^{-2}\right)$ & FF (\%) & $\operatorname{PCE}^{\mathrm{a}}(\%)$ \\
\hline- & PDPP3T:PCBM & 0.67 & 14.8 & 66.1 & $6.2(6.2 \pm 0.1)$ \\
\hline $\mathrm{CH}_{3} \mathrm{NH}_{3} \mathrm{PbI}_{3-x} \mathrm{Cl}_{x}$ & PCBM & 0.89 & 18.2 & 63.6 & $10.3(10.2 \pm 0.2)$ \\
\hline $\mathrm{CH}_{3} \mathrm{NH}_{3} \mathrm{PbI}_{3-x} \mathrm{Cl}_{x}$ & PDPP3T:PCBM & 0.93 & 22.9 & 57.1 & $12.2(11.8 \pm 0.5)$ \\
\hline $\mathrm{CH}_{3} \mathrm{NH}_{3} \mathrm{PbI}_{3-x} \mathrm{Cl}_{x}$ & PDTP-DFBT:PCBM & 0.92 & 21.1 & 56.7 & $11.0(10.7 \pm 0.5)$ \\
\hline
\end{tabular}

a) Data and statistics are based on 10 cells of each condition, and the average value is provided in parentheses.
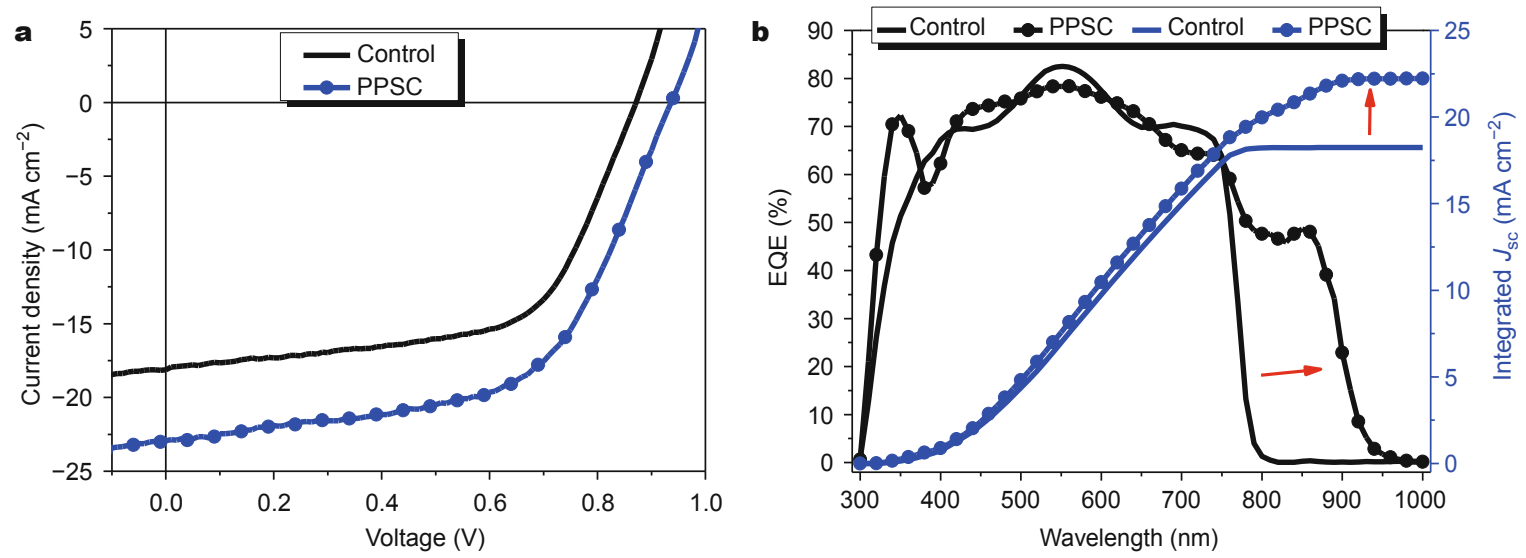

Figure 3 (a) Current density vs. voltage $(J-V)$ curves for the control perovskite/PCBM device and the PPSCs based on PDPP3T:PCBM BHJ under an illumination of $\mathrm{AM} 1.5 \mathrm{G}$ and $100 \mathrm{~mW} \mathrm{~cm}^{-2}$, and (b) the corresponding EQE spectra and integrated $J_{\text {sc }}$ plots for the control perovskite/PCBM and PPSC devices. 
Fig. $3 \mathrm{~b}$ shows the EQE characteristics for the two types of devices. For the PPSC device, a calculated $J_{\mathrm{sc}}$ of $22.1 \mathrm{~mA}$ $\mathrm{cm}^{-2}$ was confirmed by integrating the EQE curve for a standard AM 1.5 solar spectrum. This value is consistent with the $J_{\mathrm{sc}}$ measured from the $J-V$ test $\left(22.9 \mathrm{~mA} \mathrm{~cm}^{-2}\right)$, confirming the accuracy of the performance evaluation. As observed from the UV-vis spectra of the PDPP3T and perovskite in the solid film (Fig. 2), the main absorption peaks of the PDPP3T:PCBM and perovskite are quite different. Therefore, it is simple to differentiate and quantify the individual contributions from the perovskite and PDPP3T during photocurrent generation. The substantial improvement of the EQE in the NIR region offers an additional current density of $\sim 5 \mathrm{~mA} \mathrm{~cm}^{-2}$ for the control perovskite:PCBM solar cell.

Atomic force microscopy (AFM) was performed to understand the interface contact of the $\mathrm{BHJ}$ for different polymer/PCBM weight ratios on perovskite films. As shown in Figs $4 \mathrm{a}-\mathrm{c}$, the surface $\mathrm{BHJ}$ film with a 1:4 weight ratio is rather smooth, with a minimum root-mean-square roughness $\left(R_{\mathrm{q}}\right)$ of $4.07 \mathrm{~nm}$, whereas the $\mathrm{BHJ}$ blend films with 1:2 and 1:6 weight ratios exhibit relatively high $R_{\mathrm{q}}$ values of $5.41 \mathrm{~nm}$ and $9.52 \mathrm{~nm}$, respectively. Fig. $4 \mathrm{~d}$ also depicts the phase image of the $\mathrm{BHJ}$ layer for a 1:4 weight ratio. The formation of fibrillar and bicontinuous domains provides more pathways for electron transport and enhances the cell performance [44]. This suggests that controlling over the polymer:PCBM weight ratio is critical to achieving a high efficiency in the perovskite/BHJ solar cells.

The successful application of the PDPP3T motivated further investigations into the newly designed polymers in PPSC devices. We further selected a superior SBG polymer, poly[2,7-(5,5-bis-(3,7-dimethyloctyl)-5H-dithieno[3,2-b: $2^{\prime}, 3^{\prime}$-d] pyran)-alt-4,7(5,6-difuoro-2,1,3-benzothiadiazole)] (PDTP-DFBT) $\left(E_{\mathrm{g}}=1.38 \mathrm{eV}\right.$, see Fig. 1c) developed by Dou et al. [45] to verify the applicability of this method. As reported, the PDTP-DFBT exhibited a much broader and stronger EQE over the UV-vis-NIR region, which afforded a record high efficiency in tandem polymer solar cells [24]. Moreover, PDTP-DFBT simultaneously possesses a high photoresponse in the NIR region (EQE $>60 \%)$ and an excellent PCE of over $8 \%$ in a simple structured polymer solar cell. Fig. 5a illustrates the typical $J-V$ curves of the PPSC devices for an AM 1.5 G illumination (100 mW $\mathrm{cm}^{-2}$ ). We further fabricated PPSC devices based on perovskite and PDTP-DFBT:PCBM BHJ. Similarly, an improved PCE of $11.0 \%$ and a high NIR EQE of up to $40 \%$ was realized together. Thus, a high $J_{\mathrm{sc}}$ of $21.1 \mathrm{~mA} \mathrm{~cm}^{-2}$ was obtained compared with the control perovskite device.

Overall, the integration of various cases of high performance SBG polymers with complementary absorptions into the control perovskite photovoltaic device is a prom-
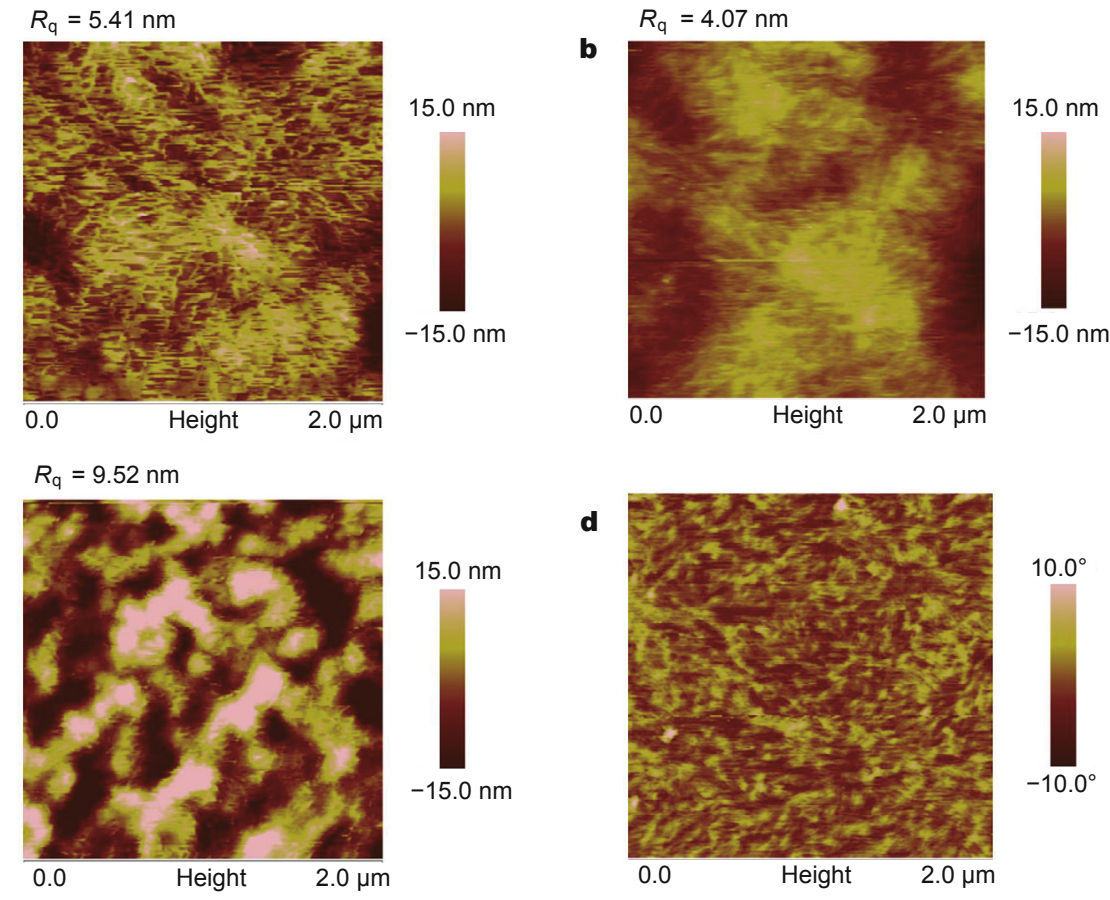

d

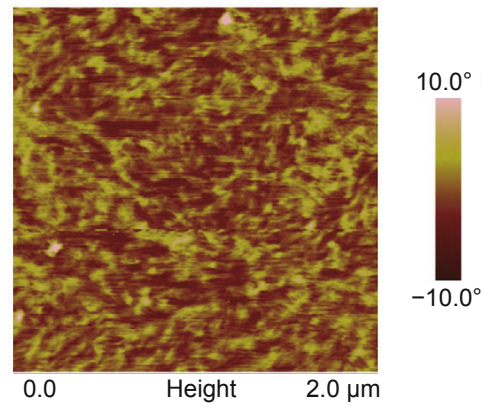

Figure 4 AFM height images of the PDPP3T:PCBM BHJ layers for (a) 1:2, (b) 1:4 and (c) 1:6 weight ratios on the top of the perovskite film and (d) AFM phase image of the PDPP3T:PCBM (1:4) BHJ layers on the top of the perovskite film. 

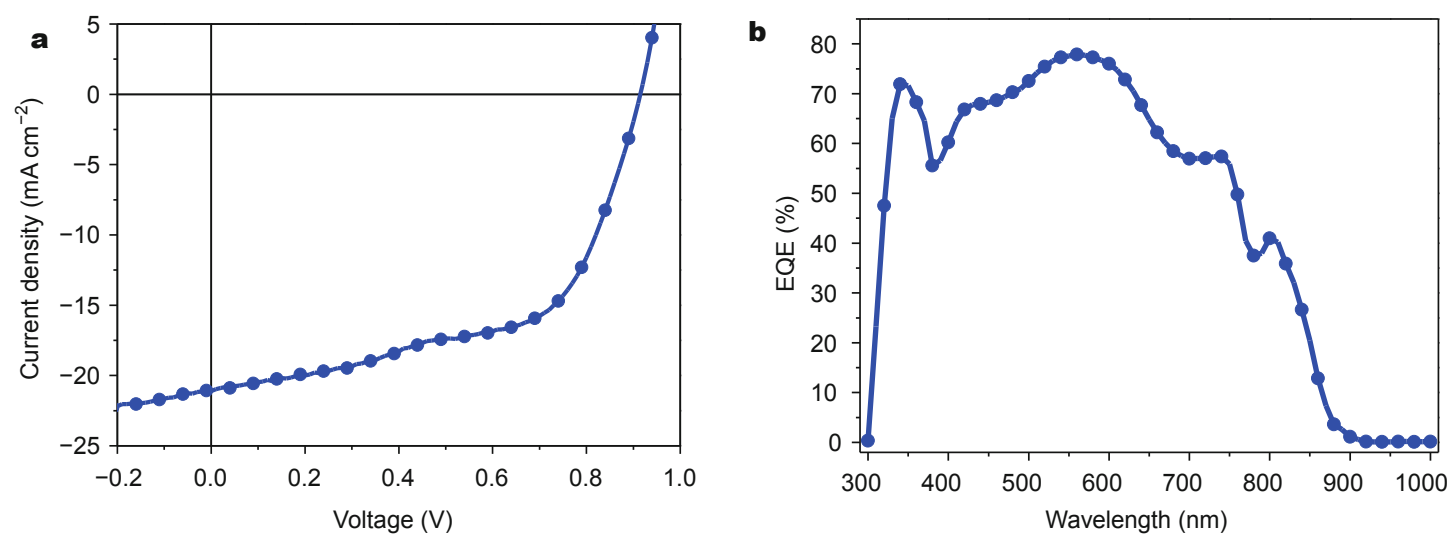

Figure 5 (a) $J-V$ curves for an illumination of AM $1.5 \mathrm{G}$ and $100 \mathrm{~mW} \mathrm{~cm}^{-2}$ and (b) the corresponding EQE spectra of the PPSC based on PDTP-DFBT.

ising strategy to enhance the $J_{\text {sc }}$ and NIR photoresponse. Currently, the efficiency of PPSC is limited by a relatively low FF. A possible hypothesis for the reduction of the FF is that, for the perovskite layer, the carrier diffusion length and the charge mobility is much larger than that of the $\mathrm{BHJ}$ layer, and thus, unbalanced exciton diffusion and accumulated charge at the perovskite/BHJ interface may eventually induce exciton/carrier recombination due to the low builtin potential between ITO and Al electrodes. Further efforts should be devoted to interface engineering for this type of PPSC device.

\section{CONCLUSION}

In this study, we have successfully demonstrated a remarkable enhancement $(\sim 20 \%)$ to the $J_{\text {sc }}$ of the control perovskite photovoltaic devices by combining SBG polymer and perovskite as absorbers in a single solar cell device. Consequently, a considerable photoresponse in the NIR region with an EQE exceeding 40\% was realized in the perovskite/PDPP3T:PCBM-based PPSC. The PCE in the optimized perovskite/PDPP3T:PCBM-based PPSC device reaches over $12 \%$, which is much higher than that of solar cells based on PDPP3T:PCBM ( 6.2\%) and perovskite/ PCBM ( 10.3\%). Further modifications to the contacts of the $\mathrm{BHJ} /$ perovskite and the $\mathrm{BHJ} /$ metal interfaces are being tested in an effort to achieve better device efficiencies. Our results indicate that the photoresponse region and the device performance of PPSCs can be effectively manipulated by screening small band gap polymers in bulk-heterojunction systems. Most importantly, the SBG polymer:fullerene $\mathrm{BHJ}$ absorbers offer more opportunities to realize higher efficiencies in conventionally structured perovskite/fullerene solar cells and other types of single or multiple junction hybrid solar cells, considering the increasing efforts dedicated to developing SBG polymers. It is highly expect- ed that insertion of an SBG BHJ layer will have a positive impact on the photovoltaic performance of solar cell devices based on wide band gap perovskites, such as $\mathrm{CH}_{3} \mathrm{~N}$ $\mathrm{H}_{3} \mathrm{I}_{x} \mathrm{Br}_{3-x}, \mathrm{CH}_{3} \mathrm{NH}_{3} \mathrm{PbBr}_{3}$.

\section{EXPERIMENTAL SECTION}

\section{Materials}

$\mathrm{CH}_{3} \mathrm{NH}_{3} \mathrm{I}$ and PDPP3T $\left(M_{\mathrm{n}}=102.3 \mathrm{~kg} \mathrm{~mol}^{-1}, \mathrm{PDI}=2.5\right.$, condition: $140^{\circ} \mathrm{C}, 1,2,4$-trichlorobenzene) was sourced from Solarmer Energy, Inc. and $\mathrm{PbCl}_{2}$ was purchased from Alfa Asear. PDTP-DFBT was synthesized in our laboratory using Yang's report [45] as a reference. The other chemicals are commercially available products and used without any further purification. The PEDOT:PSS (AI 4083) and high purity $\mathrm{Al}$ are commercially available products. All of the commercially available compounds and solvents were used without any further purification.

\section{Solar cell fabrication}

The procedures for the fabrication of control perovskite/ PCBM solar cells were derived from the previous report by You et al. [6] $\mathrm{CH}_{3} \mathrm{NH}_{3} \mathrm{I}$ and $\mathrm{PbCl}_{2}$ were mixed in anhydrous $N, N$-dimethylformamide (DMF) with a molar ratio of 3:1. The perovskite precursor solution was stirred at $60^{\circ} \mathrm{C}$ overnight and then filtered using $0.45 \mu \mathrm{m}$ polytetrafluoroethylene (PTFE) filters prior to use in device fabrication. Experimentally, the processing details of the PDPP3T/ PCBM and PDTP-DFBT/PCBM BHJ absorbers are consistent with the reported methods $[40,41,45]$. The fabrication procedures for the PPSC devices are as follows: ITO-coated glass substrates were cleaned stepwise in detergent, water, acetone, and isopropyl alcohol under ultrasonication for 15 min each before being subsequently dried in an oven for $30 \mathrm{~min}$. A thin layer (ca. $35 \mathrm{~nm}$ ) of PEDOT:PSS (AI 4083) 
was spin-coated onto the ITO surface, which was pre-treated using ultraviolet ozone for $15 \mathrm{~min}$. After being baked at $150^{\circ} \mathrm{C}$ for approximately $20 \mathrm{~min}$, the substrates were transferred into a nitrogen-filled glove box $\left(<1\right.$ ppm $\mathrm{O}_{2}$ and $\left.\mathrm{H}_{2} \mathrm{O}\right)$. Based on our previous work [40,41], a ternary solvent mixture of $o$-dichlorobenzene (DCB), chloroform (CF) and 1,8-diiodooctane (DIO) is the best solvent system to process the PDPP3T:PCBM photoactive layer [40,41]. This solvent system was also used in this work with an identical volume ratio of 76:19:5. Then, $90 \mathrm{~nm}$-thick BHJ layers with different polymer/PCBM weight ratios were deposited on the top of $340 \mathrm{~nm}$-thick perovskite layers. Finally, Al electrodes with a thickness of $100 \mathrm{~nm}$ were deposited on the top of the $\mathrm{BHJ}$ layers by thermal evaporation in a high purity vacuum. The completed PPSCs were tested in a $\mathrm{N}_{2}$-purged glove box $\left(<10\right.$ ppm $\mathrm{O}_{2}$ and $\left.\mathrm{H}_{2} \mathrm{O}\right)$.

\section{Sample characterization}

The $J-V$ characteristics of the solar cell devices were measured using a Keithley 2400 Source Measure Unit under one sun, AM $1.5 \mathrm{G}\left(100 \mathrm{~mW} \mathrm{~cm}^{-2}\right)$, and an XES-70S1 (SANEI ELECTRIC CO., Ltd.) solar simulator (AAA grade, 70 $\mathrm{mm} \times 70 \mathrm{~mm}$ photobeam size) with $2 \mathrm{~cm} \times 2 \mathrm{~cm}$ silicon reference cell (KG3 filter [46], calibrated by the National Institute of Metrology) purchased from Enli Technology Co., Ltd. The spectral mismatch factor was calculated to be unity. The active area of the device was defined with a metal aperture mask of approximately $4.15 \mathrm{~mm}^{2}$. The EQE data were measured with a QE-R3011 Solar Cell Spectral Response Measurement System (Enli Technology Ltd., Taiwan). The surface morphology was measured using a Nanoscope V (Vecco) atomic force microscope (AFM) in tapping mode. For reliability, the preparation conditions of the samples used for the morphological studies are identical to those used for device fabrication.

\section{Received 7 November 2015; accepted 10 December 2015;} published online 11 December 2015

1 Gao F, Ren S, Wang J. The renaissance of hybrid solar cells: progresses, challenges, and perspectives. Energy Environ Sci, 2013, 6: 2020-2040

2 Chueh CC, Li CZ, Jen AKY. Recent progress and perspective in solution-processed interfacial materials for efficient and stable polymer and organometal perovskite solar cells. Energy Environ Sci, 2015, 8: 1160-1189

3 Green MA, Ho-Baillie A, Snaith HJ. The emergence of perovskite solar cells. Nat Photonics, 2014, 8: 506-514

4 Song TB, Chen Q, Zhou H, et al. Perovskite solar cells: film formation and properties. J Mater Chem A, 2015, 3: 9032-9050

5 Xiao J, Shi J, Li D, Meng Q. Perovskite thin-film solar cell: excitation in photovoltaic science. Sci China Chem, 2015, 58: 221-238

6 You J, Hong Z, Yang Y, et al. Low-temperature solution-processed perovskite solar cells with high efficiency and flexibility. ACS Nano,
2014, 8: 1674-1680

7 Xie FX, Zhang D, Su H, et al. Vacuum-assisted thermal annealing of $\mathrm{CH}_{3} \mathrm{NH}_{3} \mathrm{PbI}_{3}$ for highly stable and efficient perovskite solar cells. ACS Nano, 2015, 9: 639-646

8 Liang PW, Liao CY, Chueh CC, et al. Additive enhanced crystallization of solution-processed perovskite for highly efficient planar-heterojunction solar cells. Adv Mater, 2014, 26: 3748-3754

9 You J, Yang Y, Hong Z, et al. Moisture assisted perovskite film growth for high performance solar cells. Appl Phys Lett, 2014, 105: 183902

10 Min J, Zhang ZG, Hou Y, et al. Interface engineering of perovskite hybrid solar cells with solution-processed perylene-diimide heterojunctions toward high performance. Chem Mater, 2015, 27: 227-234

11 Xue Q, Hu Z, Liu J, et al. Highly efficient fullerene/perovskite planar heterojunction solar cells via cathode modification with an amino-functionalized polymer interlayer. J Mater Chem A, 2014, 2: 19598-19603

12 Sun C, Xue Q, Hu Z, et al. Phosphonium halides as both processing additives and interfacial modifiers for high performance planar-heterojunction perovskite solar cells. Small, 2015, 11: 3344-3350

13 Docampo P, Ball JM, Darwich M, Eperon GE, Snaith HJ. Efficient organometal trihalide perovskite planar-heterojunction solar cells on flexible polymer substrates. Nat Commun, 2013, 4: 2761

14 Sun K, Chang J, Isikgor FH, Li P, Ouyang J. Efficiency enhancement of planar perovskite solar cells by adding zwitterion/LiF double interlayers for electron collection. Nanoscale, 2015, 7: 896-900

15 Xia Y, Sun K, Chang J, Ouyang J. Effects of organic inorganic hybrid perovskite materials on the electronic properties and morphology of poly (3,4-ethylenedioxythiophene) : poly (styrenesulfonate) and the photovoltaic performance of planar perovskite solar cells. J Mater Chem A, 2015, 3: 15897-15904

16 Li C, Wang F, Xu J, et al. Efficient perovskite/fullerene planar heterojunction solar cells with enhanced charge extraction and suppressed charge recombination. Nanoscale, 2015, 7: 9771-9778

17 Wang L, Fu W, Gu Z, et al. Low temperature solution processed planar heterojunction perovskite solar cells with a CdSe nanocrystal as an electron transport/extraction layer. J Mater Chem C, 2014, 2: 9087-9090

18 Liu X, Yu H, Yan L, et al. Triple cathode buffer layers composed of PCBM, $\mathrm{C}_{60}$, and LiF for high-performance planar perovskite solar cells. ACS Appl Mater Interfaces, 2015, 7: 6230-6237

19 Liu X, Jiao W, Lei M, et al. Crown-ether functionalized fullerene as a solution-processable cathode buffer layer for high performance perovskite and polymer solar cells. J Mater Chem A, 2015, 3: 9278-9284

20 Dou L, You J, Hong Z, et al. 25th anniversary article: a decade of organic/polymeric photovoltaic research. Adv Mater, 2013, 25: 6642-6671

21 Li Y. Molecular design of photovoltaic materials for polymer solar cells: toward suitable electronic energy levels and broad absorption. Acc Chem Res, 2012, 45: 723-733

22 Ye L, Zhang S, Huo L, Zhang M, Hou J. Molecular design toward highly efficient photovoltaic polymers based on two-dimensional conjugated benzodithiophene. Acc Chem Res, 2014, 47: 1595-1603

23 Wang F, Tan Za, Li Y. Solution-processable metal oxides/chelates as electrode buffer layers for efficient and stable polymer solar cells. Energy Environ Sci, 2015, 8: 1059-1091

24 You J, Dou L, Yoshimura K, et al. A polymer tandem solar cell with 10.6\% power conversion efficiency. Nat Commun, 2013, 4: 1446

25 Chen CC, Chang WH, Yoshimura K, et al. An efficient triple-junction polymer solar cell having a power conversion efficiency exceeding 11\%. Adv Mater, 2014, 26: 5670-5677 
26 Zuo L, Chang CY, Chueh CC, et al. Design of a versatile interconnecting layer for highly efficient series-connected polymer tandem solar cells. Energy Environ Sci, 2015, 8: 1712-1718

27 Li K, Li Z, Feng K, et al. Development of large band-gap conjugated copolymers for efficient regular single and tandem organic solar cells. J Am Chem Soc, 2013, 135: 13549-13557

28 Cheng P, Yan C, Li Y, Ma W, Zhan X. Diluting concentrated solution: a general, simple and effective approach to enhance efficiency of polymer solar cells. Energy Environ Sci, 2015, 8: 2357-2364

29 Chen LM, Hong Z, Li G, Yang Y. Recent progress in polymer solar cells: manipulation of polymer:fullerene morphology and the formation of efficient inverted polymer solar cells. Adv Mater, 2009, 21: 1434-1449

30 Huang Y, Kramer EJ, Heeger AJ, Bazan GC. Bulk heterojunction solar cells: morphology and performance relationships. Chem Rev, 2014, 114: 7006-7043

31 Liu F, Gu Y, Jung JW, Jo WH, Russell TP. On the morphology of polymer-based photovoltaics. J Polym Sci Part B Polym Phys, 2012, 50: 1018-1044

32 Chen CC, Bae SH, Chang WH, et al. Perovskite/polymer monolithic hybrid tandem solar cells utilizing a low-temperature, full solution process. Mater Horiz, 2015, 2: 203-211

33 Liu Y, Hong Z, Chen Q, et al. Integrated perovskite/bulk-heterojunction toward efficient solar cells. Nano Lett, 2015, 15: 662-668

34 Wang K, Liu C, Du P, Zheng J, Gong X. Bulk heterojunction perovskite hybrid solar cells with large fill factor. Energy Environ Sci, 2015, 8: 1245-1255

35 Liu C, Wang K, Du P, et al. Efficient solution-processed bulk heterojunction perovskite hybrid solar cells. Adv Energy Mater, 2015, 5: 1402024

36 Zuo C, Ding L. Bulk heterojunctions push the photoresponse of perovskite solar cells to $970 \mathrm{~nm}$. J Mater Chem A, 2015, 3: 9063-9096

37 Bijleveld JC, Zoombelt AP, Mathijssen SGJ, et al. Poly(diketopyrrolopyrrole-terthiophene) for ambipolar logic and photovoltaics. J Am Chem Soc, 2009, 131: 16616-16617

38 Li W, Furlan A, Hendriks KH, Wienk MM, Janssen RAJ. Efficient tandem and triple-junction polymer solar cells. J Am Chem Soc, 2013, 135: 5529-5532

39 Hendriks KH, Heintges GHL, Gevaerts VS, Wienk MM, Janssen RAJ. High-molecular-weight regular alternating diketopyrrolopyrrole-based terpolymers for efficient organic solar cells. Angew Chem Int Ed, 2013, 52: 8341-8344
40 Ye L, Zhang S, Ma W, et al. From binary to ternary solvent: morphology fine-tuning of D/A blends in PDPP3T-based polymer solar cells. Adv Mater, 2012, 24: 6335-6341

41 Ma W, Tumbleston JR, Ye L, et al. Quantification of nano- and mesoscale phase separation and relation to donor and acceptor quantum efficiency, $J_{\mathrm{sc}}$, and FF in polymer:fullerene solar cells. Adv Mater, 2014, 26: 4234-4241

42 Liu J, Shao S, Fang G, et al. High-efficiency inverted tandem polymer solar cells with step-Al-doped $\mathrm{MoO}_{3}$ interconnection layer. Sol Energy Mater Sol Cells, 2014, 120: 744-750

43 Zhao W, Ye L, Zhang S, et al. Ultrathin polyaniline-based buffer layer for highly efficient polymer solar cells with wide applicability. Sci Rep, 2014, 4: 6570

44 Guo X, Zhang M, Tan J, et al. Influence of D/A ratio on photovoltaic performance of a highly efficient polymer solar cell system. Adv Mater, 2012, 24: 6536-6541

45 Dou L, Chen CC, Yoshimura K, et al. Synthesis of $5 \mathrm{H}$-dithieno [3,2-b:2', 3'-d]pyran as an electron-rich building block for donoracceptor type low-bandgap polymers. Macromolecules, 2013, 46: 3384-3390

46 Ye L, Zhou C, Meng H, et al. Toward reliable and accurate evaluation of polymer solar cells based on low band gap polymers. J Mater Chem C, 2015, 3: 564-569

Acknowledgements This work is funded by the National Natural Science Foundation of China (91333204 and 21325419), and the Chinese Academy of Sciences (CAS) (XDB12030200). Ye L thanks Mr. Peng Jing (Solarmer Materials, Inc., Beijing) for the generous supply of $\mathrm{CH}_{3} \mathrm{NH}_{3} \mathrm{I}$. Hou $\mathrm{J}$ thanks the CAS-Croucher Funding Scheme for Joint Laboratories for their support.

Authors contribution Ye L and Hou J designed the experiment protocols and wrote the draft. Fan B and Ye L contributed to the control device. Yang B, Qin Y, and Zhang $\mathrm{H}$ assisted the device optimization. Zhang S and Li S synthesized the polymers. Qin Y did the AFM measurements. All authors provided comments to the draft. Hou J and Ye L directed the project.

Conflict of interest The authors declare that they have no conflict of interest.

Supplementary information Supplementary data are available in the online version of this paper. 


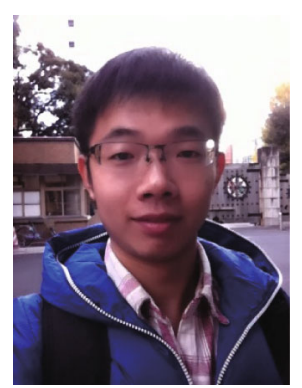

Long Ye was born in 1988. He received his $\mathrm{PhD}$ degree in polymer physics and chemistry from ICCAS in 2015 under the supervision of Prof. Jianhui Hou. Currently, he is a postdoctoral research associate working with Prof. Harald Ade at North Carolina State University. His current research interests are developing high-efficiency organic solar cells and revealing the critical factors related to the morphology/performance of organic and hybrid solar cells.

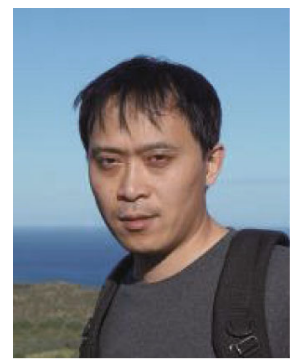

Jianhui Hou received his PhD degree in physical chemistry from ICCAS in 2006 (adviser: Prof. Yongfang Li). Then he worked as a postdoctoral researcher at Prof. Yang Yang's group at the University of California, Los Angeles (UCLA) from 2006-2008 and then director of the Research of Solarmer Energy Inc. from 2008-2010. After that, he became a full professor at ICCAS since 2010 and an adjunct professor at the University of Science and Technology Beijing since 2012. His present research focuses on design, synthesis, and application of organic/polymer photovoltaic materials.

中文摘要 近年来, 共轭聚合物和钙钛矿型有机金属卤化物被视为极具潜力的光伏材料, 引起了广泛的研究兴趣. 本文通过引入两种本 体异质结(BHJ)聚合物: 富勒烯活性层, 大幅提高了基于 $\mathrm{CH}_{3} \mathrm{NH}_{3} \mathrm{PbI}_{3-x} \mathrm{Cl}_{x}$ 的钙钛矿太阳能电池的近红外光响应特性. 其中, 基于窄带隙 聚合物PDPP3T的钻铁矿/BHJ杂化太阳能电池在近红外区域 $(800 \sim 1000 \mathrm{~nm}$ ) 内的外量子效率(EQE)峰值高达 $46 \%$, 且该区域已经超出了 $\mathrm{CH}_{3} \mathrm{NH}_{3} \mathrm{PbI}_{3-x} \mathrm{Cl}_{x}$ 型太阳能电池的光响应范围(300 800 nm). 相较于参照的钻钛矿太阳能电池, 近红外区域大幅提升的EQE为钻钛矿 / $\mathrm{BHJ}$ 杂化太阳能电池贡献了额外的电流密度 $\left(25 \mathrm{~mA} \mathrm{~cm}{ }^{-2}\right)$, 因此其光电转换效率达到了 $12 \%$ 以. 此外, 引入基于聚合物PDTP-DFBT 的BHJ 也可以使钙钛矿太阳能电池在近红外区域的 $\mathrm{EQE}$ 达到 $40 \%$ 以上. 研究结果也表明优化 BHJ的聚合物: 富勒烯比例是提高这类钙钛 矿-聚合物杂化太阳能电池性能的关键. 